\title{
Quantifying Rooftop Rainwater Harvest Potential: Case of Takoradi Polytechnic in Takoradi, Ghana
}

\author{
Ebenezer Boakye ${ }^{1}$, John Jackson Nsiah ${ }^{2}$ \\ ${ }^{1,2}$ Department of Civil Engineering, Takoradi Polytechnic, Takoradi, Ghana
}

\begin{abstract}
Rooftop rainwater harvesting potential as a source of water supply has been examined. The observed monthly rainfall records of 31 years and the current total roof area of facilities at Takoradi Polytechnic main campus as the catchment area were used. Using the simple water balance model to determine the potential for rain water harvesting, the result shows that existing structures totaling a surface area of $15069.18 \mathrm{~m}^{2}$ can harvest $9666.1 \mathrm{~m}^{3}$ of water annually which will reduce the institution's dependency on public supply system (GWCL) by $55.5 \%$ at a cost of GHC 83,232.859 when a $6000 \mathrm{~m}^{3}$ storage tank is installed. The study recommends on the necessity of installing rooftop rainwater harvesting system so as to decrease dependency on public supply system, its inherent challenges and reduction of cost.
\end{abstract}

Keywords: Quantifying, Rainwater harvesting, Potentials, Takoradi Polytechnic, water balance

\section{Introduction}

Rain water harvesting (RWH) broadly refers to the practice of capturing and storing rainwater where it falls for consumptive and non-consumptive uses (CEHI, 2009). It is a technology that is flexible and adaptable to the current and future rainfall variability and a key component of integrated water resource development and management.

RWH structures have been used for years in most countries in the semi-arid areas of East Africa (e.g. Tanzania and Kenya) and in neighboring Burkina Faso. Even in Ghana it is not a new technology. It used to be complementary water supply to rivers and streams in villages and the usage of the collected water volume from rain water harvesting was direct and without treatment. Even in the colonial era many missionary and government residences had RWH incorporated in their design. So RWH in the country was at one time universally practiced before the introduction of the first piped water supply network in 1928 at Cape Coast. Traditional RWH systems then were rudimentary but as communities became more affluent and houses were built with internal plumbing, the perceived need for RWH declined and generally fell out of favor (MWRWH, 2011). However, with the increasing pressure on available water resources due to population growth, rapid urbanization and climate change impacts, rainwater harvesting appears to be one of the most promising alternatives for supplying freshwater. Perhaps the best possible way to empower households, institutions and community to assess alternate safe water sources and to manage their own water supply, thereby reducing reliance and burden on the central water supply system. For this cause, the National rain water harvesting strategy proposed that all new government buildings be designed to harvest rainwater and existing ones re-designed to include rainwater harvesting (MWRWH, 2011).

By 2025 , the world population will be affected by moderate to severe water shortage (UN, 1997 cited in Ar Zuhairuse, 2010) and Ghana will not be spared from this impending water crisis. Already water delivery in most urban systems have become erratic and unreliable. And so, water is rationed in major urban areas due to high demand and inadequate supply. Boakye and Bentil (2011) estimated that inhabitants of Sekondi-Takoradi Metropolis connected to the public supply system (GWCL), averagely access water four (4) days per week and with increasing pollution of the Pra river (the main source of water supply), access continuous to decline.

Takoradi Polytechnic main campus like all inhabitants is faced with erratic water supply and during dry periods, production capacity of GWCL is far less than the demand. Moreover, the high water tariff puts financial stress on the institution which sometimes lead to disconnection. For instance, as at December 2013, the accumulated water bill was GHC143, 489.20. The lack of reliable supply of water often leads to unusual closure of sanitary facilities causing discomfort and environmental unsightliness. Thus, exploring opportunities for potential alternative sources such as rainwater harvesting system is key to reducing dependency on public supply system, conserve water resource and subsequently save money for other development. It is against this background that this study attempts to assess the potential for RRWH in the Polytechnic main campus. The prime objectives are to determine the average monthly volume of water that can be harvested from the total rooftop area of existing buildings and compare to their corresponding average monthly demand. The study also determines the capacity of the storage tank and quantify the amount of money the Polytechnic can save in establishing a RRWH system.

\section{Methodology}

\subsection{Description of Study Area}

Takoradi Polytechnic is a public tertiary institution with its main campus located at Effia in the Sekondi-Takoradi Metropolis of the Western Region of Ghana. It has a current student population of 8377 consisting of 5893 males and 2484 females (2015/2016 academic year). The campus is well planned with a unique layout of roads and buildings interspersed with vegetation and water channels. Building types include bungalows, halls of residence, auditorium, 


\section{International Journal of Science and Research (IJSR) \\ ISSN (Online): 2319-7064 \\ Index Copernicus Value (2013): 6.14 | Impact Factor (2015): 6.391}

libraries, administration blocks, laboratories and workshops as well as the newly constructed 'Jubilee Oil Technical Training Centre. The Polytechnic main campus is divided into "Main campus Workshop" and "Main campus Hostels" according to the GWCL metering with each section having one bulk meter. They are naturally separated by a topographically low-lying area where the main river channel flows. Monthly water demand of these two sections differ due to the different water use patterns. The buildings at "Main campus Workshop" are lecture rooms, offices, laboratories, etc. so consumption is basically for non-potable uses. On the other hand, the water use pattern at "Main campus Hostels" is mixed (potable and non-potable) since building types are halls of residence, lecturers' bungalows and lecture rooms.

\subsection{Materials and methods}

\section{Rainfall Data}

A 31-year monthly rainfall data spanning from 1984 to 2014 was gleaned from the Meteorological Station at Takoradi Airport. Microsoft excel version 2010, a windows based operating system was used in the analysis. Statistical variables determined include the average monthly and annual rainfall as well as annual minimum and maximum values. The year with the minimum monthly rainfall values (driest year) was extracted for analysis for the determination of the storage tank capacity (CEHI, 2009).

\section{Demand Rate}

Data on monthly water demand was collected from two (2) bulk meter readings each located at "Main campus Workshop" and "Main campus Hostels" respectively. The daily rates were then estimated and the total daily demand computed as the sum.

\section{Catchment Area}

Out of thirty (30) building facilities within the Polytechnic main campus, only nine (9) are located at "Main campus Hostels" with the remaining twenty-one (21) scattered within "Main campus Workshop". The collection surface which is the 'foot print' of the roof was measured using precimeter. This was done by measuring the length and width of the buildings from eave to eave and from front to rear (White et al., 2007 \& TWDB, 2005).

\section{Runoff Coefficient}

The runoff coefficient is the ratio of rainfall to runoff. It was determined from the material type for the roof and their condition. Appropriate values were chosen from the UNhabitat urban rainwater harvesting manual as used in SOPAC (2004).

\section{Storage tank capacity}

Out of the several methods used in estimating the storage requirement of the tank, the simpler (water balance) tabular method was preferred. This method which is based on rainfall variability and demand over the course of the year was applicable to periods of drought or minimum annual rainfall. Hence, the driest year of 1990 was used in the analysis (SOPAC, 2004). Also, the dry period demand method was used to estimate the minimum storage capacity of the tank. This method, on the other hand depends on the consumption rate and the longest dry period. It was also applicable since sufficient rainfall and catchment area were assured for the study area (Worm and Hattum, 2006 \& SOPAC, 2004).

\section{Results and Discussion}

As per the statistical analysis made on the 31-year monthly rainfall data, a bi-modal type of rainfall with peak values of $256 \mathrm{~mm}$ and $123 \mathrm{~mm}$ in June and October was observed as shown in Figure 1. The average annual minimum and maximum rainfall are $734 \mathrm{~mm}$ and $1557 \mathrm{~mm}$ respectively, with a long-term average annual rainfall of $1087 \mathrm{~mm}$. According to CEHI (2009), monthly values of driest year (1990) is the most ideal data to estimate the volume of harvestable water and consequently determine the minimum capacity of the storage tank.

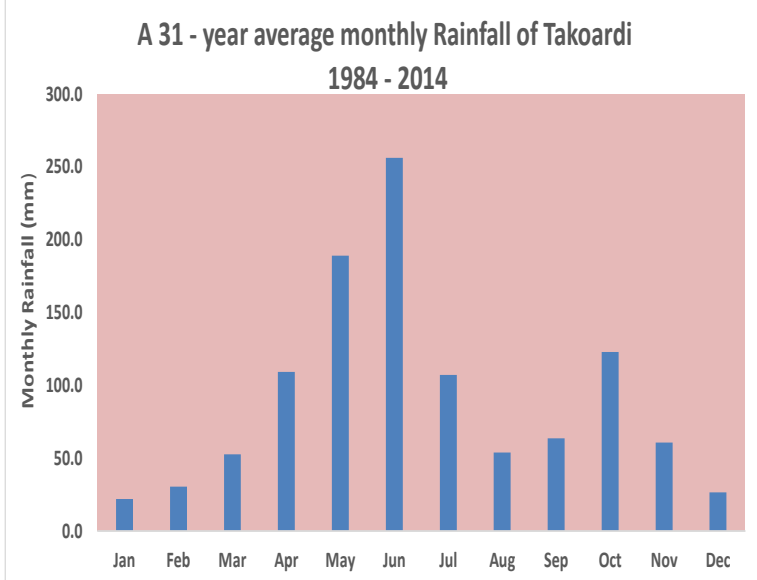

Figure 1: A 31-year average monthly rainfall of Takoradi 1984 - 2014.

\subsection{Water Balance Analysis (Main campus Workshop)}

The monthly demand according to the bulk reading was 191 $\mathrm{m}^{3}$ and the daily value was deduced to be $6.30 \mathrm{~m}^{3}$. The total roof area of the twenty-one (21) buildings was determined as $11181.84 \mathrm{~m}^{2}$ while the runoff coefficient for corrugated iron sheets and concrete tiles were also averaged to 0.85 .

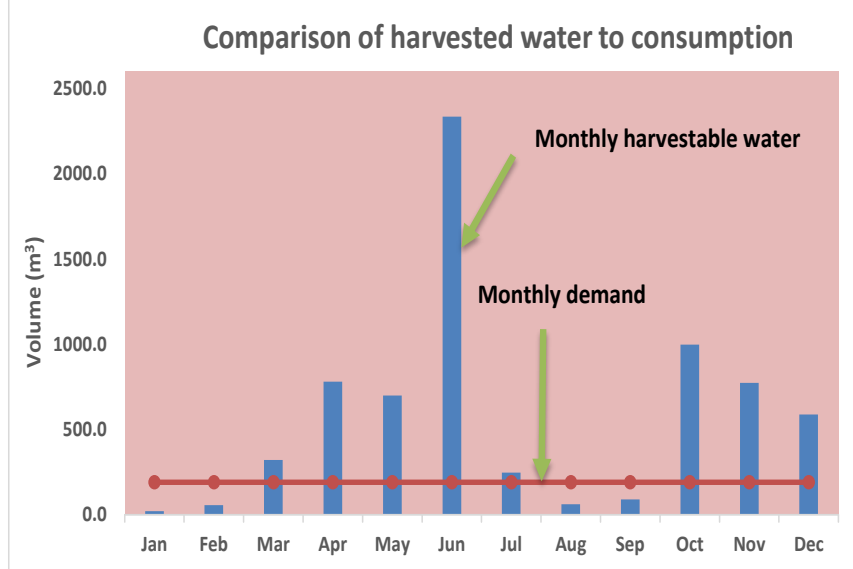

Figure 2: Monthly comparison of volume of harvestable water to demand at Main campus Workshop.

\section{Volume 5 Issue 6, June 2016 www.ijsr.net}




\section{International Journal of Science and Research (IJSR) \\ ISSN (Online): 2319-7064 \\ Index Copernicus Value (2013): 6.14 | Impact Factor (2015): 6.391}

Figure 2 compares the monthly volume of water harvested from the roof area to the demand. It can clearly be deduced from the bi-modal peak that there are two rainy seasons. Since the month of March is observed as the first month harvested water meet consumption, it can be assumed that the tank is empty in February. This assumption is indeed true because cumulative volume of water harvested during these two rainy seasons is used to satisfy consumption in the absence of rain.

Figure 3 compares the cumulative monthly volume of harvestable water to demand. This graphical method is used to determine the minimum storage requirement for the tank.

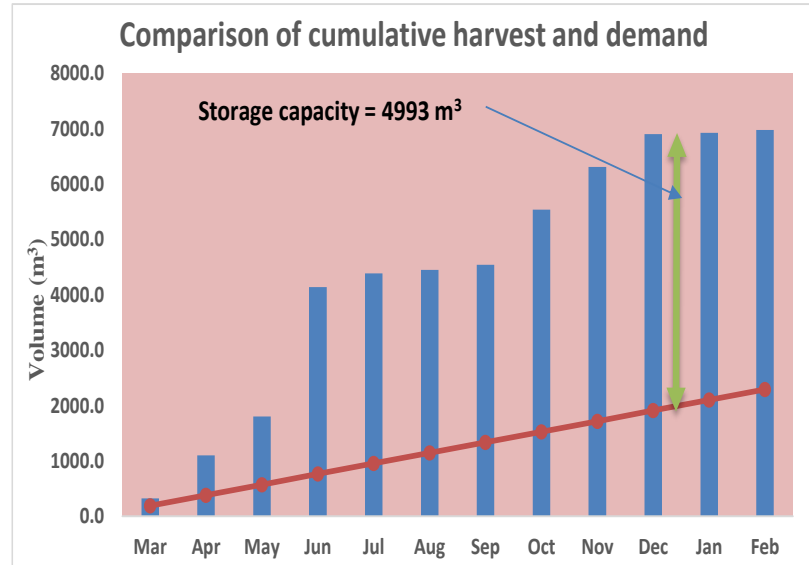

Figure 3: Monthly comparison of cumulative volume of harvested water to demand at "Main campus workshop".
It is thus deduced from Figure 3 that the minimum storage requirement occurs in the month of December with a volume of $4993 \mathrm{~m}^{3}$. This storage capacity is assured of storing all harvested water to cover the short fall in demand during dry periods.

Table 1 shows a simple monthly water balance method for the rainwater harvesting system. It determines the storage requirement of the tank by relying on the basic rule that the volume of water that can be harvested must equal or exceed the volume of water used. The monthly volume of harvested water was computed from the product of the monthly rainfall, the total area of roof footprint and the runoff coefficient. The total annual volume of water harvested is $6981.1 \mathrm{~m}^{3}$ while the total annual volume of water consumed based on the monthly demand is $2292 \mathrm{~m}^{3}$. Thus, there is a surplus of $4689.1 \mathrm{~m}^{3}$ representing an excess production of over two times the annual demand.

Table 1: A simple water balance calculation for "Main campus Workshop".

\begin{tabular}{|c|c|c|c|c|c|c|c|}
\hline Month & $\mathrm{Pt}(\mathrm{mm})$ & $V_{H}\left(m^{3}\right)$ & Cum $V_{H}\left(m^{3}\right)$ & $V_{D}\left(m^{3}\right)$ & Cum V $V_{D}\left(\mathrm{~m}^{3}\right)$ & Total Stored $\left(\mathrm{m}^{3}\right)$ & Surplus/Deficit $\left(\mathrm{m}^{3}\right)$ \\
\hline Mar & 33.8 & 321.3 & 321.3 & 191.0 & 191.0 & 130.3 & 130.3 \\
\hline Apr & 82.2 & 781.3 & 1102.5 & 191.0 & 382.0 & 720.5 & 590.3 \\
\hline May & 73.7 & 700.5 & 1803.0 & 191.0 & 573.0 & 1230.0 & 509.5 \\
\hline Jun & 245.8 & 2336.2 & 4139.2 & 191.0 & 764.0 & 3375.2 & 2145.2 \\
\hline Jul & 26.1 & 248.1 & 4387.3 & 191.0 & 955.0 & 3432.3 & 57.1 \\
\hline Aug & 6.6 & 62.7 & 4450.0 & 191.0 & 1146.0 & 3304.0 & -128.3 \\
\hline Sep & 9.6 & 91.2 & 4541.3 & 191.0 & 1337.0 & 3204.3 & -99.8 \\
\hline Oct & 105.0 & 998.0 & 5539.3 & 191.0 & 1528.0 & 4011.3 & 807.0 \\
\hline Nov & 81.5 & 774.6 & 6313.9 & 191.0 & 1719.0 & 4594.9 & 583.6 \\
\hline Dec & 62.0 & 589.3 & 6903.2 & 191.0 & 1910.0 & 4993.2 & 398.3 \\
\hline Jan & 2.3 & 21.9 & 6925.0 & 191.0 & 2101.0 & 4824.0 & -169.1 \\
\hline \multirow[t]{4}{*}{ Feb } & 5.9 & 56.1 & 6981.1 & 191.0 & 2292.0 & 4689.1 & -134.9 \\
\hline & & & & & & & \\
\hline & & & & & & 304.1 & 4689.1 \\
\hline & & 6981.1 & $\mathrm{~m}^{3} / \mathrm{yr}$ & 2292.0 & & & \\
\hline \multicolumn{6}{|c|}{ Therefore the minimum storage capacity is given as } & 4993.2 & $\mathrm{~m}^{3}$ \\
\hline
\end{tabular}

On the other hand, the total 'volume stored' which is the difference between volume of water harvest and demand is $304.1 \mathrm{~m}^{3}$. And so, the minimum capacity of the storage tank is also summed up to $4993 \mathrm{~m}^{3}$. This confirms the result of the graphical method and ultimately proves clearly that roof rainwater harvesting is feasible and economically viable at "Main campus Workshop" of the Polytechnic main campus.

\subsection{Water Balance Analysis (Main campus Hostel)}

The average monthly demand according to the bulk reading is $1259 \mathrm{~m}^{3}$ and the daily value is deduced to be $41.39 \mathrm{~m}^{3}$.
The total roof area was estimated to be $3887.34 \mathrm{~m}^{2}$ while the runoff coefficient was also averaged to 0.85 . It can be observed from Figure 4 that monthly volume of harvestable water do not meet monthly demand. This is basically due to the fact that the total area of the roof footprint is inadequate to harvest enough water to satisfy the water use pattern at "Main campus Hostel" of the Polytechnic. This shows that a storage tank facility will not be necessary since it will run dry throughout the year

\section{Volume 5 Issue 6, June 2016 www.ijsr.net}




\section{International Journal of Science and Research (IJSR) \\ ISSN (Online): 2319-7064}

Index Copernicus Value (2013): 6.14 | Impact Factor (2015): 6.391

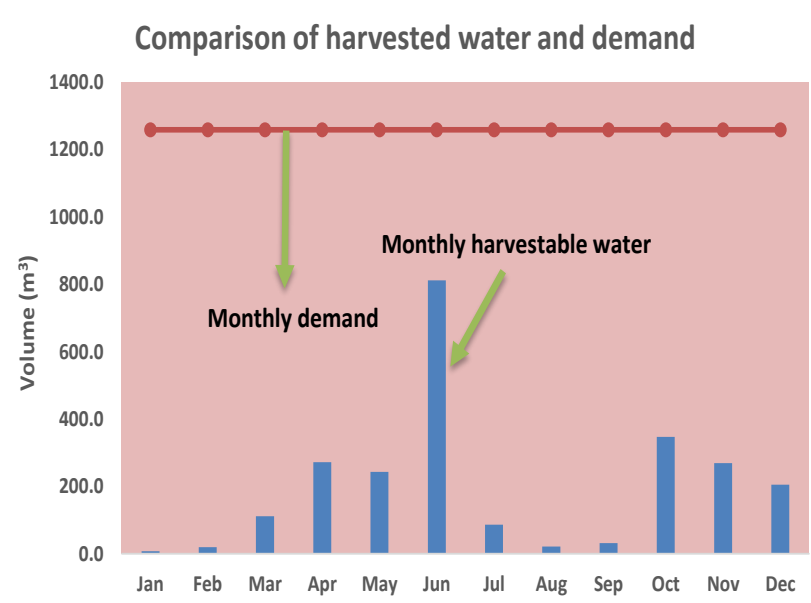

Figure 4: Monthly comparison of harvestable water to demand at "Main campus Hostel".

Table 2 shows a simple monthly water balance calculation at "Main campus Hostel" of the Polytechnic main campus. It can be seen that the total annual volume of harvestable water is $2427 \mathrm{~m}^{3}$ while that of demand is $15108 \mathrm{~m}^{3}$ indicating a huge deficit of $12681 \mathrm{~m}^{3}$ representing about $84 \%$ of the total annual demand.

Table 2: A simple water balance calculation for 'Main campus Hostel' of the Polytechnic

\begin{tabular}{|c|c|c|c|c|c|c|c|}
\hline Month & $\mathrm{Pt}(\mathrm{mm})$ & $V_{H}\left(m^{3}\right)$ & Cum $V_{H}\left(m^{3}\right)$ & $V_{D}\left(m^{3}\right)$ & Cum $v_{D}\left(m^{3}\right)$ & Total Stored $\left(\mathrm{m}^{3}\right)$ & Surplus/Deficit $\left(\mathrm{m}^{3}\right)$ \\
\hline Oct & 105.0 & 346.9 & 346.9 & 1259.0 & 1259.0 & -912.1 & -912.1 \\
\hline Nov & 81.5 & 269.3 & 616.2 & 1259.0 & 2518.0 & -1901.8 & -989.7 \\
\hline Dec & 62.0 & 204.9 & 821.1 & 1259.0 & 3777.0 & -2955.9 & -1054.1 \\
\hline Apr & 82.2 & 271.6 & 1092.7 & 1259.0 & 5036.0 & -3943.3 & -987.4 \\
\hline May & 73.7 & 243.5 & 1336.2 & 1259.0 & 6295.0 & -4958.8 & -1015.5 \\
\hline Jun & 245.8 & 812.2 & 2148.4 & \begin{tabular}{|l|}
1259.0 \\
\end{tabular} & 7554.0 & -5405.6 & -446.8 \\
\hline Jul & 26.1 & 86.2 & 2234.7 & 1259.0 & 8813.0 & -6578.3 & -1172.8 \\
\hline Aug & 6.6 & 21.8 & 2256.5 & \begin{tabular}{|l|}
1259.0 \\
\end{tabular} & 10072.0 & -7815.5 & -1237.2 \\
\hline Sep & 9.6 & 31.7 & 2288.2 & \begin{tabular}{|l|}
1259.0 \\
\end{tabular} & 11331.0 & -9042.8 & -1227.3 \\
\hline Jan & 2.3 & 7.6 & 2295.8 & \begin{tabular}{|l|}
1259.0 \\
\end{tabular} & 12590.0 & -10294.2 & -1251.4 \\
\hline Feb & 5.9 & 19.5 & 2315.3 & \begin{tabular}{|l|}
1259.0 \\
\end{tabular} & 13849.0 & -11533.7 & -1239.5 \\
\hline Mar & 33.8 & 111.7 & 2427.0 & \begin{tabular}{|l|}
1259.0 \\
\end{tabular} & 15108.0 & -12681.0 & -1147.3 \\
\hline Average & & 202.2 & & & & & \\
\hline Total & & 2427.0 & $\mathrm{~m}^{3} / \mathrm{yr}$ & 15108.0 & & & \\
\hline nerefo & $m$ & gum st & e capa & s give & & & \\
\hline
\end{tabular}

This is because the total area of the roof footprint is comparatively small. Meanwhile, building types are predominantly halls of residence and staff bungalows and few isolated lecture halls. So, the water use pattern is mixed (potable and non-potable purposes) and this contribute to very huge consumption rate. It will therefore not be feasible to estimate the storage requirement of the tank. However, it will be necessary to consider additional catchment area or supplemental source of supply (TWDB, 2005).

Noting therefore the discrepancies in these two sections, a more comprehensive computation is considered by a merger of both (Main campus workshop and Main campus hostel) sites of the Polytechnic. This showed that October is the first month harvested water meet consumption (Figure 5). Hence, it can similarly be assumed that the tank is empty in September.

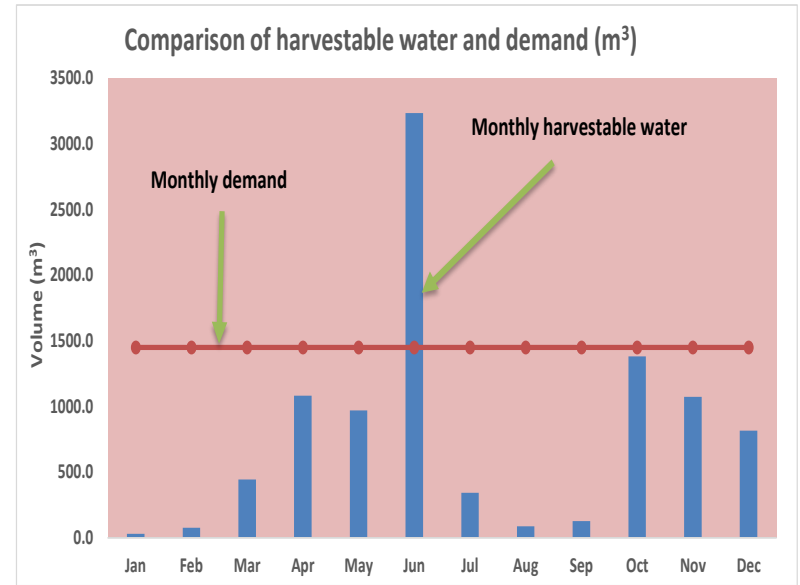

Figure 5: Monthly comparison of harvestable water to the demand of the whole Polytechnic main campus.

The simple water balance calculation as shown in Table 3 revealed that the total annual volume of harvestable water is $9666.1 \mathrm{~m}^{3}$ while that of demand is $17400 \mathrm{~m}^{3}$. This indicates a deficit of $7734 \mathrm{~m}^{3}$ representing $44.5 \%$ of the total annual demand. This implies that with the current available roof area, a minimum of $55.5 \%$ of the total annual demand can be harvested by the Polytechnic main campus. This can reduce dependency on the public supply system and financially save the Polytechnic an amount of GHC 83,232.859.

Table 3: A simple water balance calculation for the Polytechnic community

Volume 5 Issue 6, June 2016 www.ijsr.net

Licensed Under Creative Commons Attribution CC BY 


\section{International Journal of Science and Research (IJSR) \\ ISSN (Online): 2319-7064}

Index Copernicus Value (2013): 6.14 | Impact Factor (2015): 6.391

\begin{tabular}{|c|c|c|c|c|c|c|c|}
\hline Month & $\mathrm{Pt}(\mathrm{mm})$ & $V_{H}\left(m^{3}\right)$ & Cum $V_{H}\left(m^{3}\right)$ & $V_{D}\left(m^{3}\right)$ & Cum $V_{D}\left(m^{3}\right)$ & Total Stored $\left(\mathrm{m}^{3}\right)$ & Surplus/deficit $\left(\mathrm{m}^{3}\right)$ \\
\hline Oct & 105.0 & 1381.8 & 1381.8 & 1450.0 & 1450.0 & -68.2 & -68.2 \\
\hline Nov & 81.5 & 1072.5 & 2454.4 & 1450.0 & 2900.0 & -445.6 & -377.5 \\
\hline Dec & 62.0 & 815.9 & 3270.3 & 1450.0 & 4350.0 & -1079.7 & -634.1 \\
\hline Jan & 2.3 & 30.3 & 3300.6 & 1450.0 & 5800.0 & -2499.4 & -1419.7 \\
\hline Feb & 5.9 & 77.6 & 3378.2 & 1450.0 & 7250.0 & -3871.8 & -1372.4 \\
\hline Mar & 33.8 & 444.8 & 3823.0 & 1450.0 & 8700.0 & -4877.0 & -1005.2 \\
\hline Apr & 82.2 & 1081.8 & 4904.8 & 1450.0 & 10150.0 & -5245.2 & -368.2 \\
\hline May & 73.7 & 969.9 & 5874.7 & 1450.0 & 11600.0 & -5725.3 & -480.1 \\
\hline Jun & 245.8 & 3234.8 & 9109.4 & 1450.0 & 13050.0 & -3940.6 & 1784.8 \\
\hline Jul & 26.1 & 343.5 & 9452.9 & 1450.0 & 14500.0 & -5047.1 & -1106.5 \\
\hline Aug & 6.6 & 86.9 & 9539.8 & 1450.0 & 15950.0 & -6410.2 & -1363.1 \\
\hline Sep & 9.6 & 126.3 & 9666.1 & 1450.0 & 17400.0 & -7733.9 & -1323.7 \\
\hline & & & & & & 13459 & -7734 \\
\hline Sum & & 9666 & & & & & \\
\hline \multicolumn{6}{|c|}{ Therefore minimum storage capacity is given as } & 5725 & $\mathrm{~m}^{3}$ \\
\hline
\end{tabular}

The minimum storage capacity of the tank according to the simple water balance calculation is given as $5725 \mathrm{~m}^{3}$. The demand side approach also computed the minimum storage capacity of the tank from the product of the total consumption rate and total dry period resulting in a volume of $5800 \mathrm{~m}^{3}$. As a rule of thumb, a minimum storage capacity of $6000 \mathrm{~m}^{3}$ is recommended (CEHI, 2009).

\section{Conclusion and Recommendation}

The potential rooftop rainwater harvesting system has been evaluated for Takoradi Polytechnic main campus using the current roof area, bulk meter readings (GWCL) and 31 years recorded monthly rainfall gleaned from the Meteorological Station at Airport, Takoradi.

The assessment revealed that at "Main campus Workshop", the annual water balanced analysis resulted in a huge surplus of $4689.1 \mathrm{~m}^{3}$ whilst at "Main campus Hostel", huge deficit of $12681 \mathrm{~m}^{3}$ was realized. However, the simple water balance calculation for the whole Polytechnic main campus showed that total annual volume of $9666.1 \mathrm{~m}^{3}$ can be harvested (driest year) as against total demand of $17400 \mathrm{~m}^{3}$. This signifies that even in times of minimum annual rainfall, $55.5 \%$ of water demand by the institution can be provided through rain water harvesting. This can indeed reduce spending on water bills by GHC 83,232.859 annually. The minimum storage capacity of the tank according to the rule of thumb is given as $6000 \mathrm{~m}^{3}$.

It is therefore recommended that, the institution should as a matter of urgency employ rain water harvesting technique in order to reduce its dependency on the public water supply and lessen the burden of utility bills.

\section{References}

[1] Ar Zuhairuse Md Darus (2010). Potential Development of Rainwater Harvesting in Malaysia, Proceedings of the 3rd WSEAS Int. Conf. on ENERGY PLANNING, ENERGY SAVING, ENVIRONMENTAL EDUCATION, ISSN: 1790-5095, ISBN: 978-960-474093-2

[2] Boakye, E. and Bentil, J. (2011). Access to Potable Water in Sekondi-Takoradi and its Environs. Takoradi
Polytechnic Journal of Technology, Tpoly J. Tech. Vol1 (1) $2011: 1-8$.

[3] CEHI (2009). Rainwater while you can catch it Handbook for Rainwater Harvesting for the Caribbean. A practical guideline featuring best practices for rainwater harvesting in Small Island Caribbean environments. Prepared by 'The Caribbean Environmental Health Institute' \& funded by 'United Nations Environment Programme (2009).

[4] MWRWH (2011). Improvement of Water Sector Performance Management Framework. NATIONAL RAINWATER HARVESTING STRATEGY, Final Report, December, 2011

[5] SOPAC, (2004). Harvesting the Heavens - Guidelines for Rainwater Harvesting in Pacific Island Countries. South Pacific Applied Geoscience Commission for the United Nations Environment Programme (UNEP). Collaborators: the Tonga Community Development Trust (TCDT) and the Swedish International Development Agency (SIDA). Available on-line at http://www.sopac.org/data/virlib/JC/JC0178.pdf

[6] SOPAC (2004). Harvesting the Heavens - A Manual for Participatory Training in Rainwater Harvesting South Pacific Applied Geoscience Commission for the United Nations Environment Programme (UNEP). Collaborators the Tonga Community Development Trust (TCDT) and the Swedish International Development Agency (SIDA). Available on-line at: http://www.sopac.org/data/virlib/MR/MR0544.pdf

[7] TWDB (2005). The Texas Manual on Rainwater Harvesting. Third Edition. Texas Water Development Board. Available on-line at: http://www.twdb.state.tx.us/publications/reports/Rainwa terHarvestingManual_3rdedition.pdf

[8] White, K.H., Soward, L.R. \& Shankle, G., (2007). Harvesting Storing and treating Rainwater for Domestic Indoor Use. Texas Commission on Environmental Quality.

[9] Worm, J. and Hattum, T.V., (2006). Rainwater harvesting for domestic use, Digigrafi, Wageningen, The Netherlands. $1^{\text {ST }}$ edition, ISBN: $90-8573-053-8 \&$ ISBN: 92-9081-330-X

\section{Volume 5 Issue 6, June 2016 www.ijsr.net}

